\title{
THOUGHT-PROVOKING 'CONTAMINATION': APPLIED LINGUISTICS, LITERACIES AND POSTHUMANISM
}

\author{
'CONTAMINAÇÃO' QUE FAZ PENSAR: LINGUÍSTICA \\ APLICADA, LETRAMENTOS E PÓS-HUMANISMO
}

\section{Nara Hiroko Takaki*}

\begin{abstract}
This paper purports to present some characteristics of the posthuman perspective and relate them to contemporary understanding of applied linguistics and literacy studies with preliminary activities in this direction and interrogations for future studies. As interdisciplinary studies, posthumanism draws on Deleuze and Guattari's notion of assemblage (2005) and has been gaining relevance according to theorists such as Barad (2007), Bennet (2010), Braidotti (2018) and Pennycook (2018), among others. One of their concerns is the future of language research, teaching, learning and enacting in philosophical, transcultural and educational ways. Barad (2007) and Bennet (2010)) use the terms humans and nonhumans while Braidotti (2018) and Pennycook (2018) write humans and non-humans. At times, Bennet (2010) prefers human-nonhuman(s) to emphasize the idea of assemblage. They consider such agents in vibrant interconnected assembles within a broader range of semiotic, spatial and ethical complexities in the emergence of posthuman humanism as Braidotti (2018) argues. This calls for applied linguistics and literacy studies willing to recognize that they themselves are products of such entanglements for which a revision of ontologies influencing epistemologies and methodologies might be productive. Keywords: posthuman perspective; applied linguistics; expanding literacy studies.
\end{abstract}

\section{RESUMO}

Este artigo se propõe a apresentar características da perspectiva pós-humanista e relacionálas a entendimentos contemporâneos sobre linguística aplicada e estudos de letramentos, com atividades preliminares nessa direção e indagações para futuros estudos. Como estudos interdisciplinares, o pós-humanismo se inspira no conceito de assemblage de Deleuze e Guattari (2005) e vem ganhando relevância de acordo com teóricos como Barad (2007), Braidotti (2018), Bennet (2010), Pennycook (2018), dentre outros. Uma das preocupações desses estudiosos é o futuro da pesquisa, ensino, aprendizagem de/em línguas/linguagens e práxis em termos filosóficos, transculturais e educacionais. Barad (2007), Bennet (2010) usam os termos humanos e nãohumanos enquanto Braidotti (2018) e Pennycook (2018) registram humanos e não-humanos. Às vezes, Bennet (2010) prefere humanos-nãohumanos para enfatizar a ideia de assemblage. Consideram tais agentes em assemblage vibrante em meio a uma gama ampliada de complexidades semióticas, espaciais e éticas na emergência do humanismo pós-humano, conforme argumenta Braidotti (2018). Isso requer uma linguística aplicada e estudos de letramentos dispostos a reconhecer que eles próprios são produtos de

\footnotetext{
* Universidade Federal de Mato Grosso do Sul (UFMS), Mato Grosso do Sul, MS, Brasil. narahi08@gmail.com, http://orcid.org/0000-0001-8574-5842
} 
tais emaranhamentos, para os quais uma revisão de ontologias influenciando epistemologias e metodologias mostra-se produtiva

Palavras-chave: perspectiva pós-humana; linguística aplicada; expandindo estudos de letramento.

\section{INTRODUCTION}

Beyond pleasure and pain, life is a process of becoming, of stretching the boundaries of endurance.

(BRAIDOTTI, 2018)

\footnotetext{
The world is an ongoing open process of mattering through which "mattering" itself acquires meaning and form in the realization of different agential possibilities. Temporality and spatiality emerge in this processual historicity. Relations of exteriority, connectivity, and exclusion are reconfigured. The changing topologies of the world entail an ongoing reworking of the very nature of dynamics (BARAD, 2003, p. 18)
}

In this epigraph, the agential possibilities refer to the vibrant relationality in humans and non-humans (BRAIDOTTI, 2018) and humans and nonhumans (BARAD, 2003) forces, which challenge the assumptions and cultural model of European humanism. Such a model consists of "lethal exclusions and fatal disqualifications" (BRAIDOTTI, p. 15) of otherness (beyond the human world) and this view has been greatly influencing contemporary studies of language, culture and the planet in and out of Europe.

One of the legacies of the westernized thought, knowledge and selfrepresentation is the notion of human as a consequence of criteria based on purity. Under the belief that purity could be guaranteed in relation to genome, class, sex and accents, this man ${ }^{2}$ would teach and change de 'exotic' life for the 'better', making it adapt to the predicates of the classical Antiquity and Italian Renaissance as represented by da Vinci's Vitruvian Man, in accordance with the cited author.

To balance the radical triumph of the reason and, at the same time, pursuing overarching 'truths', the 'new' Vitruvian Woman "forged a bond of solidarity between

1. In this article, I maintain the theorists' terminologies and I use human-nonhuman(s), mainly in the last session of this paper, to reinforce the entanglement of the continuous process of transformation rather than a concrete and additive one. I use nonhuman(s) to mark the space, place and things in general.

2. Except for citations, I opt for lowercase letters to begin the words "man" and "woman" as a marker of my stance against human exceptionalism. In the same vein, I use "reason" and "truth" in lowercase to stress my solidarity with the authors advocating the 'end' of humanism in the new human and social sciences. 
one and the many, which in the hands of the second feminist wave in the 1960s, was to follow the principle of "political sisterhood" (BRAIDOTTI, 2018, p. 21). The Vitruvian Woman fell into the same trap as the Vitruvian Man for both claimed universal ideals despite criticizing masculinist universalism through the social movements from 1970 onwards. One of the consequences of this paradigm was the constant production of discourses around emancipation and progress eliminating those subjects who 'were 'different from' and meant 'less than' (BRAIDOTTI, 2018, p. 28) the ideal former Man/Woman of the classical Humanism.

In accordance with the cited theorist, new critical epistemologies ${ }^{3}$ standing against the European humanism have offered alternative views of what is meant by human, suggesting the Foucaultian identification of the subject as both man and object (BRAIDOTTI, 2018, p. 151), an ironic attitude which recognize that male and female categories are socio-historical constructs. In this sense, homogeneous and normative identities and narratives assigned the human agent a central place in charge of development. By death, the aforementioned author suggested an irony for man continued to operate in powerful ways to the extent that a new status would be provided: an "ex-Man" (BRAIDOTTI, 2018, p. 151), still Man ,but a transformed one.

While recognizing the fact that Man was no longer the unique agent on epistemological, ethical and political grounds, Braidotti (2018, p. 27) argues in favor of a posthuman condition which "reflects the complex and nomadic nature of contemporary social systems and of the subjects that inhabit them". This is not to say, however, that the posthumanist proposition is immunized against limitations. On one hand, contemporary technology-driven, global-local economies and progress in the name of capitalism and nationalism have fixed identities. On the other hand, they have forced people to rethink their alternatives to experience less travelled paths taking into account the collective self to understand "zoe" (BRAIDOTTI, 2018, p. 103), another word for life.

In this sense, Braidotti (2018) calls for a different framework through taking a critical stance towards three strands to develop posthumanism ${ }^{4}$. The first one is related to philosophy. Within this field, posthumanism encompasses life as a process far from reconstructing the subjects' identities and ideological positions as being steady and homogeneous, leaving little room for novelties. The second

3. For example, interdisciplinary studies, such as: feminism, ethnicity, gender, post-colonial media, new media, human rights and cultural studies.

4. Posthumanism is not totally new. Instead of just blaming humans it draws attention to the web of forces crisscrossing the sociocultural and material contexts. 
strand involves Latour's (2005) society and technology studies, including the actants $s^{5}$, which do not account for knowledge produced in more dialogical ways with Humanities and Sciences, resulting in fragmented epistemologies. This view shared by Pennycook (2018), who thinks Latour's Actor Network Theory does not embrace the question of contingencies and the power of invention. The third strand refers to Franklyn, Lury an Stacy's (2000, p. 26 apud BRAIDOTTI, 2018, p. 40) panhumanity, an interconnection between human and nonhuman ${ }^{6}$ studies, which ends up being rather analytic and does not grasp a sustained revision of subjectivity (to be detailed in the next sections ${ }^{7}$ ).

Posthumanism draws on Deleuzean and Guattarian's insights and it presupposes that "issues such as norms and values, forms of community bonding and belonging as well as questions of political governance assume and require a notion of subject" (BRAIDOTTI, 2018, p. 42). A redefined conception of subjectivity entails a posthuman subject, which in turn, operates within multiplicity. Multiplicity resembles a "rhizome" which "ceaselessly establishes connections between semiotic chains, organizations of power, and circumstances relative to the sciences and social struggles" (DELEUZE, GUATTARI, 2005, p. 28).

In this logic, such authors $(2005$, p. 28$)$ claim that the semiotic chains are multimodal in their nature, for they reconnect "biological, political, economic, diverse regimes of signs and state of things of differing status", and that is why "collective assemblages of enunciation function directly within machinic assemblages" (DELEUZE, GUATTARI, 2005, p. 28) ${ }^{8}$. The word assemblage was 'coined' by these philosophers for whom "An assemblage is precisely this increase in the dimensions of a multiplicity that necessarily changes in nature as it expands its connections" (DELEUZE, GUATTARI, 2005, p. 28), that is, an open-ended and effervescent process of forces in concert with each other. This model constantly produces assemblages within assemblages.

On this account, resorting to quantum physics, Barad (2003, p. 25) develops "agential realism": "how and why we must understand in an integral way the roles of human and nonhuman, material and discursive, natural and cultural factors in scientific and other practices." In other words, agential realism means a blurring of the subject-object distinction. She explains that there is not a necessary

\footnotetext{
5. Actants can be (non)human agents/materials working in tandem (LATOUR, 2005).

6. In this particular case, Braidotti (2018) uses human and nonhuman studies instead of human nonhuman studies.

7. It is not the aim here to fill in the gaps and provide answers to such authors' critique, though.

8. They draw on Spinoza's affective body, which assumes things, the mind/body as transformative modes in action
} 
correspondence between things and words as a medium between both subject and object and "language has been granted too much power" (BARAD, 2003, p. 132) when the everyday life is based on doing and undoing by means of intra-action. She explains:

The neologism 'intra-action' signifies the mutual constitution of entangled agencies. That is, in contrast to the usual 'interaction', which assumes that there are separate individual agencies that precede their interaction, the notion of intra-action recognizes that distinct agencies do not precede, but rather emerge through their intra-action" (BARAD, 2003, p. 33).

This is equivalent to say that an emerging "intra-action" of bodies, objects and discourses "matter", argues Barad (2003, p. 20), since it distributes the power among such elements and provides "diffractions" - instead of reflections - with richer notions of engagement of subject-object, nature-culture.

With this outline, we present characteristics of posthuman subjectivity exposing ecological, technological and ethical issues, a contemporary understanding of posthuman applied linguistics and literacy studies, preliminary activities in this direction and interrogations as thought provoking contributions. We do not celebrate poshumanism as a universal salvationist discourse, though.

\section{POSTHUMAN SUBJECTIVITY ASSEMBLING WITH THE OTHERS}

Braidotti (2018) claims for attention to integrate posthuman studies with scientific and technological complexities departing from the paradoxes and their dilemmatic implications for political subjectivity. This entails, according to her, a broader discussion on legal and ethical issues concerning, for example, a robot's autonomy to decide between life and death and to what extent the designer of such robot is to be responsible or not for pre-defined rules.

To substantiate posthumanism, Braidotti (2018) reminds us that a more productive form of contemporary critique assumes that concepts of reason and equality are not mutually exclusive with the colonial European experience, while referring to post-colonial theorists mainly Said (2004, p. 55 apud Braidotti, 2018, p. 153). Emphasizing a sense of inter-connectivity, she relies on ecological, environmental posthumanists such as Shiva's (1997 apud BRAIDOTTI, 2018) to 'heal the earth' and focus on the significance of human and non-human lives amalgamated to "non-Western neo-humanism" (BRAIDOTTI, 2018, p. 49) as a holistic approach to reconsider the survival of material needs, cultural values such 
as education, health and identity reconstruction. To this end, it might be useful to conceive of

the critical posthuman subject within an eco-philosophy of multiple belongings, as a relational subject constituted in and by multiplicity, that is to say a subject that works across differences and is also internally differentiated, but still grounded and accountable (BRAIDOTTI, 2018, p. 49).

Otherwise stated, the nomadic subject is one who transcends anthropocentrism through developing a strong sense of always becoming, that is, enacting ways of transforming his/her own vulnerable conditions in conjunction with more collective and communal strategies including the non-humans' energy and participation.

Undertaking a more productive choice with a pro-active attitude instead of lamenting the violent colonial past, be it in relation to Man or to non-human, characterizes the ethics and the "affirmative politics" of Braidotti's (2018, p. 47) posthuman condition. Becoming a nomad of Europe means combining critique and creativity to work in tandem and dislocate the focus to assume posthumanism as a project of possibilities.

Owing to the fact that contemporary subjectivity is tied to the world in its integrity, including science and technologies studies at full speed in relation to the humanities, as explained by Braidotti (2018, p. 58), coming to terms with unprecedented, creative and critical visions of subjectivity and materialism seems more congruent for the development of "planetary subject formations" (BRAIDOTTI, 2018, p. 104).

Nonetheless, these formations invoke constraints in the nomadic subject's surroundings. For example, under Liberal labels, science produces commodities for the global economy ranging from food cooking to world music (BRAIDOTTI, 2018, p. 49). Biotechnological interventions in animal and human health, accumulation of information in itself, data banks on social networking, DNA testing etc. are also sold as a vital force of prosperous life, for which Braidotti (2018, p. 51) recommends a critical scrutiny. The risk here is to treat humans and non-humans in the same way as long as they generate profits at all costs. The cited author exemplifies the spirit of global capitalism disguised as posthuman through the image of Da Vinci's Vitruvian Man on a Starbucks coffee mug, where the printed motto would be "I shop, therefore I am" (BRAIDOTTI, 2018, p. 63).

The Vitruvian man in post-anthropocentrism is the one "who incessantly sees himself struck by a particular state of mind while watching films about natural disaster, destruction of all sorts", Braidotti (2018, p. 64-65) alerts us. This condition 
is greatly influenced by "a negative predicament maintaining the urbanized, masculine and white man on the top of the hierarchy leaving animals, plants and the environment at its bottom", she complements. A posthuman proposal, therefore, is guided by considering the transformation of the subjectivity and the production of knowledge.

With a view to expanding on subjectivity and knowledge, Braidotti (2018) suggests working on human-animal interaction in ways that go beyond affection and mercy for animals, that is, beyond the epistemological premise centered on mere animal rights as in the case of "old and new feminist vegetarian and vegan critical theory" (BRAIDOTTI, 2018, p. 77) fighting meat-eating. For her, simply extending humanist values and privileges to non-humans might not render productive, for, in that way, the dichotomy between human and animal prevails, preserving the former as superior to the latter and, thus, closing down spaces for the "post-human as becoming-animal" (BRAIDOTTI, 2018, p. 67).

The point is actually to embark on a sort of "strangement" (BRAIDOTTI, 2018, p. 72) of how animals appropriate the 'oxygen' from the same environment that humans inhabit and how to understand their use of bodies to do and cope with things in ways that affect the whole environment. Also important is grasping how this might change (or not) the situations and the relations between humans and other life forms in their broader senses. Bennet (2010) declares:

the human body is itself a composite of many different it-bodies, including bacteria, viruses, metals, etc. and that when we recognize a resemblance between a human body and a nonhuman one, sometimes the connecting link is a shared inorganicism ${ }^{9}$.

In this vein, hierarchies from the enlightenment humanism which place the humans on their top levels reduce agency in general to human-only agency. "The point about posthuman relations, however, is to see the interrelation human/animal as constitutive of the identity of each" (BRAIDOTTI, 2018, p. 79), since the center of the world assemblage of "evolution" is now shared by other non-human beings (technology, objects, animals, plants). This means that deeper research into ethical and political epistemologies revolving around human/animal relations might be necessary to translate complexity through an understandable language yet to be developed. Going along with this principle, Taylor's (2016, p. 18, italic emphases in the original) concept of research might be useful:

9. From: https://philosophyinatimeoferror.com/2010/04/22/vibrant-matters-an-interview-with-janebennett/ 
posthumanist research is an enactment of knowing-in-being that emerges in the event of doing research itself. In opening new means to integrate thinking and doing, it offers an invitation to come as you are and to experiment, invent and create both with what is (already) at hand and by bringing that which might (or might not) be useful, because you don't yet know, into the orbit of research.

In other words, creativity and a positive attitude to deal with contingencies while relating humans and non-humans in such investigations might be required. The distinction between man and animal has been blurred when one thinks of how marketable these two concepts are. Braidotti (2018) states that animals are great sources of food, labor in agriculture and living materials for scientific experiments. Dolly the sheep, dogs and monkeys in space exploration, King Kong and Avatars in the film industry all attest animals tend to be as disposable as humans. Not only are they explored, but have also benefitted from advanced medical treatment. This approximation would illustrate "the inter-relation human/animal as constitutive of the identity of each", as Braidotti (2018, p. 79, author's emphases) argues. How animals" lives influence the contextual social and cultural conditions in which man acts, performs and lives life certainly deserves more research.

\section{ENACTING ECOLOGICAL AND TECHNOLOGICAL RELATIONS IN POSTHUMANISM}

To complicate humanism, a planetary or geo-centered dimension to approximate post-humanism as "becoming-earth" is another crucial aspect in Braidotti's views (2018, p. 66). Changes in the climate and the risk of (non)human extinction call for an updating of critical theory, but "the social constructivist approach of Marxist, feminist and post-colonial analysis does not completely equip them [critical theorists] to deal with the change of spatial and temporal scale engendered by the post-anthropocentric or geo-centered shift" (BRAIDOTTI, 2018, p. 84). The apparent ecological vision in Marxist, feminist and post-colonial perspectives ${ }^{10}$ highlights the division between nature and culture, earth and industrialization and reinforces a harmonious relationship between humans and their ecological habitat as "a way of humanizing the environment", as she criticizes (2018, p. 86).

What seems to be desirable, therefore, is a nomadic subject who is also concerned with "the geo-centered dimension of the potentiality of the nature-

10. Although a revision of critical theories is relevant for the cited author, for the theorists working on social constructivist approaches of Marxism, feminism and post-colonialism it may not be so. 
culture", as Braidotti $(2018$, p. $82-85)$ characterizes it, that is, a subject capable of producing processes of "defamililiarization of the dominant notions of the subject through a language that shocks established habits and deliberately provokes imaginative and emotional reaction" (BRAIDOTTI, 2018, p. 87). This is because

Dis-identification involves the loss of familiar habits of thought and representation in order to pave way for creative alternatives... it implies the open-ended, inter-relational, multi-sexed and trans-species flows of becoming through interaction with multiple others" (BRAIDOTTI, 2018, p. 89.

This is similar to Barad's (2017) position, who advocates in favor of inviting the pluralized other human non-human responses, considering distinct but geocentered agencies. In this case, ecology matters and so does technology. Hence, the mutual modification of man and machine foregrounded by technological advances has lead the Vitruvian Man to become cybernetic ${ }^{11}$, according to Braidotti's (2018, p. 91), which seems to be more congruous with the digital times.

One of the consequences of the cybernetic man, that is, the human as a self-controlling, teleological system, not different, in this sense, from machines and thermodynamic systems, including ecological systems, is the ethical dimension of "transversal relations that generate new modes of subjectivity, also known as ecosophy. Eco-sophy aims at crossing transversally the multiple layers of the subject, from interiority to exteriority and everything in between" (BRAIDOTTI, 2018, p. 92).

Drawing on Guattari's (1995, p. 26 apud BRAIDOTTI, 2018, p. 93) three ecologies: the environment, the social nexus and the psyche, Braidotti highlights the importance of the interconnection among, for example, the greenhouse effect, the status of women, racism, xenophobia and frantic consumerism. This is exactly what she means by a nomadic interconnectivity, whose subject is polyvocal and distant from given and legitimized conceptions of identity, values and social praxes. Reinventing intersubjectivity presupposes, thus, a "focus of collectively enacted, non-profit-oriented experimentations with intensity with what we are actually capable of becoming" (BRAIDOTTI, 2018, p. 92).

Counting only on autopoietic human subjectivation, in accordance with Guattari (1995, p. 2 apud BRAIDOTTI, 2018, p. 94) "accounts for both living organisms, human and self-organizing systems, and also for inorganic matter, the machines". The emphasis lies on a productive view of technology. Technology

11. A 3d Vitruvian man robot model design animation can be accessed at: https://www.shutterstock. com/pt/video/clip-11021117-3d-vitruvian-man-robot-model-design-animation 
transforms in combination with the posthuman subject taking into account their "embedded and embodied nature" in the form of transversal connections, which call into question languages and discourses to express "the generative "wetware" (BRAIDOTTI, 2018, p. 96) of this subject and the flows of effects stemmed from the relation between the "not-One" to the "multiple others" (BRAIDOTTI, 2018, p. 100). In this sense, a technologically mediated "we" sharing the world with other lives and non-humans is desirable to understand zoe/life (BRAIDOTTI, 2018, p. 103) in vibrant, and ethical ways, a topic developed in the next section.

\section{ETHICAL DIRECTIONS IN POSTHUMANISM}

As previously clarified, creating and sensing life possibilities beyond the confines of bound identities connects man to planetary forces in contemporary ecologically mediated contexts since life is a prerogative of all the participants. A shared bond among them is crisscrossed in nature: "Death and destruction are the common denominators for the transversal alliance" (BRAIDOTTI, 2018, p. 111) from a negative point of view. For example, "post-anthropocentric technologies such as killing robots are reshaping necro-political dimensions" (BRAIDOTTI, 2018 , 129). According to the author, necro-politics is tied to a negative view of life and increases vulnerability.

In order to transform pessimism, a revised regime of bio-power might be required, following the Foucaultian (BRAIDOTTI, 2018, p. 97) allusion to death as both destructive/unsustainable and generative/virtual. This understanding looks at and into the life-death continuum with a different attitude: "Posthuman critical thought does not aim at mastery, but at the transformation of negative into positive passions!" (BRAIDOTTI, 2018, p. 134), and so the very dynamics of the humans and non-humans waves of death/life and sustainability/endurance as the epigraph in the beginning of this article suggests is likely to be constantly activated.

Far from operating under the banner of narcissism, posthuman critical theory implies living life, breaking the cycles of reproductive shapes to "self-fashion our own death" (BRAIDOTTI, 2018, p. 135) in interactions with others, making the subject "an expression of successive waves of becoming", "becoming imperceptible" to transform negativity while "making friends with impersonal death" (BRAIDOTTI, 2018, p. 1136-137). Life-death, generative and destructive aspects are not left behind in the process of reconstructing nature-culture. However, in accordance with the author, they can produce multiple, complex and inter-connected flows to a variety of possible sources of forces as agents and meanings of zoe/life. 
Departing from a less sure notion of hierarchy and from complexity seems a modest attitude, as "posthuman subjectivity reshapes the identity of humanistic practices by stressing heteronomy and multi-facet relationality, instead of autonomy and self-referential disciplinary purity" (BRAIDOTTI, 2018, p. 145). Such a choice tends to establish dialogues with a more post-anthropocentric challenge to face geo-political conflicts and technologically mediated issues, such as mass migration, sophisticated weapons, super powered corporations, to name a few, all of them articulating paradoxes and hybridities.

One example of a paradox would be the biopolitics of disability (MITCHELL, SNYDER, 2015). It has produced inclusive and exclusive mechanisms under neoliberalism: the promotion of social visibility to some disabled people in many urban spaces (for example, via the creation of sports stars supported by state apparatuses and the media) and the exclusion of the vast majority of other disabled people who cannot uphold mainstream norms.

Critical posthuman studies explode the boundaries of the classical humanities providing non-insular themes as emerging demands that are relevant for the expansion of critical theories. They do so via humble experimentation to better understand "planetary intellectual challenges by means of a robust epistemological self-reflexivity" (BRAIDOTTI, 2018, p. 150-153), which could apply, for example, the field of applied linguistics and literacy studies in posthuman times.

A modest posture recognizes that linguistic and non-linguistic realms strengthen and expose forces of becoming in sciences that are transversal in the sense that human thinking and activity are influenced by environmental and organic nuances. Furthermore, categories of conventional thought, logics and reasoning are now blended with insights coming from undisclosed knowledge and prospective social praxes. How can applied linguistics and critical literacies studies be inspired by such studies, enacting a rhizomatic encompassment of human and non-human logics for us to understand and amplify the co-presence and co-construction of the human-nonhuman ${ }^{12}$, we/they relationship, while taking into account multidirectional memories? One possible hint is provided by Braidotti (2018, p. 167), that is, "leaving the Vitruvian man to adopt notions of subjects, animals, plants, objects and non-material things which are relational and not privileged". This formulation does not eliminate anthropocentrism per se, however, as the dilemma represents an opportunity to revise its premises to develop innovative discourses and human-nonhuman ways of co-existing. On this ground, reimagining a planetary

12. The use of human-nonhuman is the author's choice as explained in the beginning of this article. 
subject that is more or less free from anthropocentrism to accommodate humannonhumans in their (dis)abilities in complicit ways seems to be an alternative.

A critique that Braidotti's theoretical construct of posthumanism (2018) receives is that, in it, the non-human relationships are celebrated, but what is missing is how, for example, coloniality (QUIJANO, 2013), decoloniality (MIGNOLO, 2000) and post-colonial (SANTOS, 2018) histories, narratives, memories and cultural practices of human-nonhuman actants emerge contingently in life reproducing (more or less, or maintaining) social inequities. We move on to posthumanist applied linguistics to check this point.

\section{HOW DOES POSTHUMANISM RELATE TO POSTHUMANIST APPLIED LINGUISTICS?}

From a humanist point of view, we can start to think of language, cognition and agency not merely as distributed across different people but rather as distributed beyond human boundaries and as playing an active role in a world that is not limited to human activity alone. (PENNYCOOK, 2018).

It is our interpretation that objects, as suggested in this epigraph, play a part of human activity and, thus, drive significant forces within the dynamics of multiple repertoires in spatiality. Pennycook (2018) illustrates this point by exposing his posthuman research speaking from the position of a diver. Following his findings, among the many perceptions he shares is thinking of the crew of a ship with indications of directions as played by the compass rose. Such objects (ship, compass rose, clothes, diving equipment, water, salt, sand, air, plants, animals, sea etc.) refer to the multiple semiotic devices with certain functions in multispatial affordances influencing the way people draw on their cultural background to make sense of the discourses and social praxes around them and their world.

In the context of gastronomy, Pennycook and Otsuji's previous research (2015) showcases the emergence of spatial and distributed repertoires in restaurant kitchens. In such places, there are encounters of different members speaking diverse languages, learning from each other, relating materiality, experience/know how to their histories and incorporating other unexpected occurrences:

\footnotetext{
A range of semiotic resources is distributed within and outside this busy workplace, crisscrossed by trajectories of people (cooks, floor staff, phone calls), artefacts (knives, sieves, plates, ingredients) and practices (washing, chopping, cooking, serving). (PENNYCOOK, 2018, p. 49)
} 
In this context, non-verbal language also interferes in multimodal (KRESS, 2003) meaning-making, which emphasizes the fact that language practice is intertwined with spatial elements other than what people have in their minds. In this way, a poshumanist applied linguistics, as Pennycook (2018, p. 51) understands it, helps redefine "language as embodied, embedded and distributed across people, places and time and not a determinate or determinable object of analysis". This means recognizing the contribution to the meanings made of the variety of languages, dialects, gestures and mimes, and by hearing, seeing, feeling, smelling, touching, speaking, postures, ways of dressing and performances, which are all connected to spatial resources involving the specific position and functions of the pieces of furniture, appliances, tools, decoration and the multimodal composition of the whole environment. If language is part of an assemblage, "the interaction, the properties of the non-human actors change the very notion of interaction".

Pennycook (2018) locates his contribution to a posthumam applied linguistics resorting to the conceptualizations of assemblage (DELEUZE, GUATTARI, 2005) and language as ongoing processes. However, he feels the need to go beyond language as adopted by applied linguistics, as explained subsequently. Referring back to the word assemblage, it is an English translation of the French word agencement. Agencement was first used by Deleuze and Guattari (2005), according to Philips (2006, p. 3). It means arrangement, fitting, that is, a way of organizing things or refers the different parts of a building, a figure, a shop, a machine, a collection of remains in archeology, or the ingredients in a recipe. Livesey (2010) explains the way he understands what Deleuze and Guattari (2005) mean by assemblage.

Assemblage are complex constellations of objects, bodies, expressions, qualities, and territories that come together for varying periods of time to ideally create new ways of functioning. Assemblages operate through desires as abstract machines or arrangements, that are productive and have function; desire is the circulating energy that produces connections. As assemblage transpires as a set of forces coalesces together, the concept of assemblage applies to all structures, from the behavior patterns of an individual, the organizations of institutions, an arrangement of spaces, to the functioning of ecologies (LIVESEY, 2010, p. 19).

As a consequence of seeing the world as assemblage, the dialectic movement of making and unmaking territories is essential for "becoming-other" in an innovative fashion, as Braidotti (2018, p. 84) signals:

Becoming is always double, that which one becomes becomes no less than the one that becomes-block (sic) is formed, essentially mobile, never in equilibrium"; and "one assemblage does not have the same forces or even speeds of deterritorialization as another 
as Deleuze, Guattari, (2005, p. 327-329) point out. The aforementioned quotations indicate the potential of ongoing interconnected forces and therefore, interrelationality matters in assemblages within assemblages in motion.

Such a logic seems fertile to bring the dialogical Bakhtinian notion of language (that is, language seen as heterogeneous and unstable, having a human agent as its user and creator, reverberating the polyphony of culture, but not nature) in touch with nonhuman relations. Namely, posthuman language complicates the Bakhtinian view of language by decentralizing human agency and incorporating distributed components and forms of nonhuman agency into dialogue. The Bakhtinian notion of dialogism already emphasizes the plurality of perspectives among the interlocutors participating in the everyday social interactions and dialogues across cultures. The tendency of bringing it to a posthumanist perspective is to expand such a view for contexts in which objects play an important role, and to redefine their dialogic relationship with their users. For instance, a wheelchair or a pair of contact lenses do not talk to their user, but they can change the way the language user understands the world and is understood by others. "Interaction is produced in emerging ways of arranging, organizing and fitting resources together that bring elements together for particular purposes", adds Pennycook (2018, p. 51).

Consequently, language, from this perspective, can be conceived of as a process of incessant becoming entangled with the non-human, a crucial insight for the theoretical-practical expansion of applied linguistics. Interaction, from Pennycook's posthumanist perspective (2018), is the way pluralized agents assemblage (as a verb) the linguistic, multimodal, spatial and semiotic resources in contingent, heterogeneous and centrifugal movements to renegotiate meanings in an everyday life always already in ontological and epistemological tension. It is possible to say assemblage works in conjunction with other different and dynamic assemblages simultaneously, pulsing life in interlinked meaning making, doing agency and being collectively in the world.

In a nutshell, assemblages should be valued in terms of "their enabling or blocking of a body, plant, machines' potential to become other and ethical alternatives for knowledge production and agency" (PENNYCOOK, 2018, p. 55). Subjects and objects are regrounded in teaching, learning, researching and enacting. Knowing and agency are co-constructed, shared and cannot be attributed only to the subject of knowledge as he/she operates with other objects in combination, dislocating hierarchical systems towards the constant process of becoming. 
Furthermore, Pennycook (2018) argues in favor of more optimism, supporting Barad (2007), Bennet (2010 and Braidotti (2018), to reconceptualize applied linguistics along post-humanist directions:

Posthumanism thus draws on multiple strands of thought and points in multiple directions, from a questioning of the centrality and exceptionalism of humans as actors on this planet, or the relationship to other inhabitants of the earth, to a re-evaluation of the role of objects and space in relation to human thought and action, or the extension of human thinking and capacity through various forms of human enhancement (PENNYCOOK, 2018, p. 5).

It seems clear, therefore, that a consideration of ecological dimensions of languages within assemblages of all sources of production and circulation of knowledge has more chances to transform conventional views of language which have historically prioritized seeing and hearing to the detriment of other senses.

Regarding the question of animals, Pennycook (2018) agrees with Braidotti (2018) in her critique of mere animal rights as another mechanism founded on an idealized human. People have to understand "how animals are capable of learning from one another (birds), demonstrating abstract thought (apes), solving problems (whales, turtles), and acting in collaborative ways in difficult times" Pennycook (2018, p. 87) declares. Animal communication "is part of a broader approach to language in and beyond linguistics" and "this demands a more expansive version of language then is common in applied linguistics" (PENNYCOOK, 2018, p. 87). It has been observed that a science of emergence coming to 'new' answers impacting the zeitgeist with distributive, mobile and transformative authorship is already in the air.

Moving from westernized and conventional notions of language that aimed at a transparent communication and automatic mutual understanding among the speakers, Pennycook and Otsuji (2017) calibrate research in posthuman applied linguistics through metrolingualism. By metrolingualism, these authors mean a broader semiotic relation in spaces in ways that meanings are associated with objects, people, animals, affect and places, without a fixed hierarchy among the senses and humans and non-humans. In this way, cityscapes and landscapes are discursively constructed under complex synaesthesia, literacies and semiotic assemblages that deserve closer attention.

Metrolingualism is a form of posthuman practice with strong arguments to reinforce that meanings are produced as a local practice (PENNYCOOK, 2010) through translingual (CANAGARAJAH, 2013) renegotiations in the encounter of languages, spaces, resources, senses, and interests on the part of the speakers. This is illustrated by a situation in a bistro in Tokyo run by a Maghrebi background 
person, in which a Japanese costumer is served a dish made of an ingredient whose name is not common to either (PENNYCOOK, 2018, p. 95-99). The linguistic, spatial, multimodal, cultural repertoires make different meanings emerge to the point that confusion and persistence prevail. However, other strategies, such as resorting to words in French, in Japanese and the owner's asking the other staff members for engagement/embodiment, are all part of the norm in the posthuman language as assemblage: misunderstanding and understanding. They engage in a variety of social practices and make choices based on how semiotic resources, not only linguistic, become available in that particular space and they contingently experiment with interactions through translingual, transcultural epistemology and strategies.

Speakers in a posthuman world are seen as agents who accept the ambiguous, uncertain and slippery nature of more-than-interactions and operate under collective interests to co-construct knowledge in non-linear and opaque styles. This attitude and approach are useful and they challenge conventional ways of transforming and/ or transposing experiences into language.

Furthermore, non-humans "are vibrant objects in temporary assemblages (that include chairs, tablecloths, food, drink, cutlery, conversations) as actants that interpellate us into diverse forms of socialization. It is not just a question of what humans bring to the table but also what the table brings to the human" (PENNYCOOK, 20180, p. 121). This shows evidence "that human language should not be demarcated as the only way forward", Pennycook proceeds (2018, p. 121), but seen as a complex process of observing perceiving, thinking, evaluating and theorizing to refashion relationships, discourses and the planet (BRAIDOTTI, 2018) in rhizomatic modes (DELEUZE, GUATTARI, 2005) "emphasizing the critical of critical social theory" (PENNYCOOK, 2018, p. 123).

The idea here is to change the paradigms in teaching, learning, researching and enacting with/through language which have granted humans a special status separated from the non-human world, and to draw attention to the emergence of insights for different questions around knowledge and relationship, a point some applied linguists have already been developing interdisciplinarily. Humans exist for things and vice versa in the ways that multiple bodies come into being in the world. This might turn applied linguistics into an embodied science to better understand how, for example, language praxis can be expanded through/with semiotic assemblages of human-nonhumans.

In this direction, power is activated and shared into multiple actants and so is authorship: men, children, refugees, indigenous people, animals, machines, plants 
and material things, history and politics, as Pennycook (2018, p. 135-137) considers the ethical responsibility of each of them over the planet's common good.

A posthumanist applied linguistics, for Pennycook (2018, p. 140), signifies doing research and developing pedagogical praxes that resist and transform the centrality of humans in the assemblage, disrupting notions "that language learning happens only in our heads, that literacy is a matter only of textual decoding, that agency is something that only humans have and that the world revolves around the human subject." In doing so, its aim is to "unsettle the position of humans as the monarchs of being and to see humans as entangled and implicated in other things" (PENNYCOOK, 2018, p. 126, italic emphases in the original). He illustrates with his findings in an experience as a diver, through which his relationship with the sharks has transformed. They do not have to be unproductive enemies. This being the case, seeing, hearing, feeling, touching, smelling, organizing, fitting things along with the non-humans might help in the redesigning of tasks, activities and projects with a new status for the material world together with new ethical reasons to explain why actants work/live the way they do.

Apart from the critique of human exceptionalism, one wonders which other ways are available, in Pennycook's (2018) view, for a posthumanist applied linguistics to meet with the issues of language and social inequalities that he has approached in his former transgressive applied linguistics (PENNYCOOK, 2007).

Building on historical and cultural dynamics of colonialism and postcolonialism, for example, might generate problematizations with a view to expand a posthuman applied linguistics along the lines of the following questions: a) To what extent does a posthumanist applied linguistics favor the less prestigious social classes, their cultural capitals and histories together with the less dominant materiality in entangled ways?, b) Can Pennycook's posthumanist applied linguistics run the risk of having a neoliberal endpoint?, and c) How can posthumanist applied linguistics accommodate the global north and southern theories in entangled agencies? It is our belief that rather than solving problems, posing different questions is already a result of posthuman teachings, and that food for thought like this might inspire new avenues for future a Brazilian and an international posthuman applied linguistics.

\section{EXPANDING LITERACIES FROM A POSTHUMAN PERSPECTIVE}

What can we do with the current models of literacies, whose urban spaces (including rural landscapes) tend to be "the science park of the future" forcing the universities to become "multi-versity?", Wernick (2006, p. 561 apud, BRAIDOTTI, 
2018 , p. 179) interrogates. Universities are said to be promising post-anthropocentric spaces that reflect, serve and actualize sustainability/endurance within "poly-lingual realities" (BRAIDOTTI, 2018, p. 184), problematizing the discourses of relativism, pluralism and individualism based on a politics of difference.

Such reflections have long been put forward by literacy scholars who depart from conflicts as productive rather than merely negative. Responding to these interrogations implies changing the terms of the conversation through unsettling colonial forces in (non)human-kind touching the literacy universe. Critical education has emerged within uneven relations of power. Freire, (2005), Mignolo (2000, 2010) and Santos (2018), among others, have long been criticizing the continuous historical domination of the people from the North over the ones in the South (North and South as social/political spaces that go beyond geographical borders). These scholars' projects seek to undermine colonial explorations that occur through capitalism in the peripheries while, at the same time, stressing that the future depends on non-Eurocentric teachings. Now, a more posthuman attitude, including ontological human-nonhuman tensions, might be expected in their studies (or not). Such tensions generate "new" epistemological interrogations as the very process of becoming: To what extent are the crimes committed against the lives in the South worse than those committed in the North, considering these crimes feed back into one another and taking into account that there are internal oppressions on both sides? How have nonhumans transformed the ontological, cosmological and epistemological indigenous premises as people on both sides have gotten in contact with technology, for example? How has the confrontation between the North and the South established dialogues in ways that include the nonhuman agency that is so relevant for both? How can the North and the South learn from/with the ethical contemporary agency, if there is something to be taught without eliminating the conflitcs? How can posthuman intersubjectivity transform the Vitruvian Man that haunts the Brazilian liberalism as becoming posthuman implies transforming a post-anthropocentric autonomous view of subjectivity, geared towards capitalist opportunism?

An innovative and larger constellation of philosophical, linguistic, political, ethical, epistemological, ontological, methodological and educational deliberation questioning the presumptions of human exceptionalism is called for. For example, Hackett and Somerville's (2017) ethnographic studies on young children's movements (marching and banging drums) and sounds (jiggling) around a museum, climbing in and out of the river, scooping up mud and spinning in circles showed the decentering of children and the emergence of their co-dependence on the role 
of the objects and places. In other words, making space for their ways of knowing (epistemologies) and ways of being (ontologies) all coming into play was brought to the fore to go beyond the theory/practice divide, to improve qualitatively research on languages. The researchers point out that early literacy should not be confined to the classroom, linearity and chronology. The implications of "emergent posthuman praxes are that young children's literacies are seen not only as embodied sensory experiences, but embedded in and inseparable from their entanglement with the world", a key point they assessed (HACKETT; SOMERVILLE, 2017, p. 28).

In this regard, a more rhizomatic orientation of not-known, not-determined forms of knowledge production and research brings ongoing processes of becoming to the fore better than absolutist and universal answers and/or reliance on immutable states of being and living. If theories based on assemblages of heterogeneous and dynamic interconnections are friendly political and ethical companions to deconstruct the idea of animate/inanimate distinctions, then posthumanism intersects with non-Western cultural traditions in that one particular vision of human no longer holds true for all humans. And that is congruous with the modest way with which Braidotti (2018) ponders her understanding of posthumanism.

One of the most important tenets of critical education is the development of critical consciousness (FREIRE, 2005) to renegotiate meanings in situations where uneven relations of power predominate and in ways that all parts could be benefited. To this end, understanding the relationship between self and other in light of their collective sociohistorial differences is fundamental (SOUZA, 2011). In this way, drawing on the importance of difference/alterity to promote changes in society in order to transform fixed hegemonic and colonial hierarchies becomes the modus operandi of similar pedagogies working on social and ethical purposes.

Critical consciousness is not an aim to be pursued or aspired to as a linear progression of teaching, learning, researching and enacting, though. For Freire (2005), discarding difference is not the goal. An important perception is that the other's time, position and location in history and his/her engagement with the world might not be meaningful for one self in the same way as this one self constructs the world in ways that might not make sense for the other. In order to approach the different selves and their others, a change in the epistemological focus presupposes that strategies and procedures cannot be carried out in isolation. Approaching otherness requires curiosity, as Freire (2005) teaches us and this means to permit my self to be contaminated by the other, to reimagine the world from the perspective of the other, in a dialogue with my own perspective. This is philosophically constructed in the excerpt below: 
It is not from me that I know you. In terms of philosophical thinking, it is the opposite. It is from the discovery of you as the non-self of me that I turn over me and perceive as me, at the same time, as the self of me, I live the other in you. It is exactly when my self becomes the other in him, that he discovers the other in him. It is a formidable thing. (FREIRE, 2005, p. $149)^{13}$.

In this manner, coexistence and dialogue seem to be the norm now. A commitment with the other entails listening to the other's narratives, paradoxes and understanding the sociohistorical events that led him/her to think, act and enact in life in particular ways, as Souza interprets it (2011, p. 130), while exercising reflexivity. According to Freire (2005), this happens due to the fact that critics perceive

reality as process, as transformation, rather than as a static entity. [...] Critical thinking contrasts with naïve thinking, which sees "historical time as a weight, a stratification of the acquisitions and experiences of the past", from which the present should emerge normalized and "well-behaved". For the naïve thinker, the important thing is accommodation to this normalized "today". For the critic, the important thing is the continuing transformation of reality, on behalf of the continuing humanization of men" (FREIRE, 2017, p. 92, quotation marks in the original).

If reality is not something to remain untouched, as the citation stresses, both the other and my self enter a process of a broader understanding that difference separates them while keeping them together to come to terms in a dialogical fashion and to rethink ways of changing their social conditions. Instead of jettisoning difference, critical thinking turns it into a driving force to promote agency underpinning dominant paradigms.

What happens when critical literacies encounter posthumanism? A possible hint $^{14}$ is that the relationship between we/they, my self and the other (FREIRE, 2005) in posthuman times calls for the inclusion of animals, plants, objects and all the planetary forces as selves and others. In an openly mutating state, with distributed and interconnected agency, my self and the expanded nonhuman other (animal, plant, object, machine, abstract things, perhaps?) are assemblages in their

13. From the original: Não é a partir de mim que eu conheço você... é o contrário. A partir da descoberta de você como não-eu meu, que eu me volto sobre mim e me percebo como eu e, ao mesmo tempo, enquanto eu de mim, eu vivo o tu de você. É exatamente quando o meu eu vira um tu dele, que ele descobre o eu dele. É uma coisa formidável. (FREIRE, 2005, p. 149, apud SOUZA, 2011, p. 130.)

14. The aim here is to signal insights for future research and not to ask questions and respond to them with closed and complete answers for this would contradict the author's position. Also, the cited theorists recognize and assume clearly that there are epistemological and methodological issues that deserve further attention. Ontology-epistemology-methodology (TAKAKI, 2019) or Epistemology-ontology-methodology (TAKAKI, 2016) can be integrated. 
own right and the I/we cannot be apprehended apart from them, as the authors here cited have emphasized. This is a possible expansion of critical literacies as it might go beyond conventional language (and/or other semiotic means) to approach meaning making and socio-cultural human-nonhuman agency and distributed power in enmeshed flows of the porous performativity.

Dialogue as a strategy may not suffice. Freire's (2005) sayings such as: "reading the word and the world" and "What legitimized tolerance ends up teaching is that, in its experience, I learn with difference ${ }^{15 "}$ (FREIRE, 2005, p. 2) might be revisited with a view to embracing 'more-than-language'. On the one hand, to separate word and world, is to go against Barad's and others' new materialism. On the other hand, to think of differences beginning from a human-nonhuman divide may no longer be an option. Posthuman literacies presuppose understanding life ingrained in nonhumans. One possible alternative might be to complicate literacy studies by posing 'new' problems with the multiple and complex forms of agency and 'intelligence' other than those already known (linguistic, artificial, musical, interpersonal, logical-mathematical, spatial, bodly-kinaesthetic etc.) and to include not only, chimpanzees, dogs and bacteria, but atoms, molecules, wind, water, sun and so on as in agencial roles by rethinking how they all come to be developed to be/being in/with/against the world.

In this direction, "Only human beings are praxis ${ }^{16}$ - the praxis which, as the reflection and action which truly transform reality, is the source of knowledge and creation. Animal activity, which occurs without a praxis, is not creative; people's transforming activity is" (FREIRE, 2011, p. 100-101) does not particularly accommodate the proposition of there being a nonhuman praxis. Nonetheless, it is not a matter of assigning responsibility to nonhumans, as this would be a top-down human decision with human epistemology leaving the nonhumans in a submissive position to follow the instructions.

The creative and critical alternatives might be crafted with a spirit that arises out of the ethical recognition of man not seen as above the nonhumans and the contingencies. To illustrate this point, let's take the recent collapse of the dam in Brumadinho, Minas Gerais in Brazil. This shows evidence that animals, plants, rivers, equipment (mobile phones, machines, vehicles etc.), more than merely being part of that landscape, exert some power on people as vital players in life. Accessing

15. From the original: "O que a tolerância legítima termina por ensinar é que, na sua experiência, aprendo com o diferente" (FREIRE,2005, p. 2).

16. Praxis in the sense of social practice. 
their "non-verbal language" is a credential this man has not yet been granted. There is, then, much to learn with the nonhuman we/they, including the view that

\begin{abstract}
"Human" bodies are not inherently different from "nonhuman" ones. What constitutes the "human" (and the "nonhuman") is not a fixed or pregiven notion, but nor is it a freefloating ideality.[...] The differential constitution of the "human" ("nonhuman") is always accompanied by particular exclusions and always open to contestation (BARAD, 2017, p. 24, quotation marks in the original).
\end{abstract}

As a quantum physics and philosophy scholar, Barad (2017) argues for other social-material practices in which movements, entanglements, space-time enfoldings are typical to welcome other forms of engagement not with self-contained and individual ways of being, but rather with those resembling the behavior of the atoms and molecules.

This openness enables other questions and narratives as particular practices of engagement allowing for distributed responsibility instead of only concentrated on man. "This queering of responsibility marks a disruption of the usual framings of ethics that take human exceptionalism to be the unquestioned bedrock of analysis", Barad (2003, p. 6) foregrounds. Also, Pennycook reminds us that:

A sustainable ethics for non-unitary subjects rests on an enlarged sense of inter-connection between self and others, including the non-human or 'earth' others, by removing the obstacle of self-centred individualism on the one hand and the barriers of negativity on the other. (PENNYCOOK, 2018, p. 190, quotation marks in the original).

In this reasoning, what is reiterated here is: ethical posthumanism can be more productive. Corroborating this vision, Taylor (2016, p. 15) understands that

ethics is not about trying to see the world from inside someone's else's shoes - which presumes individuated bodies. Rather, it means recognizing skin not as a barrier-boundary but as a porous, permeable sensorium of connectivity with/in a universe of dynamic co-constructive and differential becomings.

In consonance with this quotation, thinking of we/they as only humans may no longer meet the requirements in terms of pluralized ontologies influencing epistemologies and methodologies for posthuman oriented life. One example of how to carry out research under this logic is to put bodies, concepts and things in motion so that undergraduate students can investigate how "curriculum is brought into being and enacted through a mutable range of posthuman materialities and spatialities", according to Taylor (2016, p. 20-21). By uniting critical thinking, questioning and creative activism, experimenting with noise, atmosphere, light, producing photos, poems, objects and writing a journal, and analyzing the 
embodied enactments of space in classroom, the author exemplifies what she means by edu-crafting, that is, research which is done in the less captive movement and performativity of the co-inhabitants, that is, the (non)human we/they, of a particular spatio-material assemblage.

In this vein, Gale (2016, p. 253-256) proposes writing as a posthuman form of activity in her research. Participants were asked to elaborate on "short pieces of diffractive writing" explaining how they had made sense of classroom noise and of their use of visual modalities while learning new material. They were supposed to share these views with their colleagues as an attempt to challenge reflexivity that tends to mirror realities from a linear perspective. As an embodied and embedded experience, it also required students to write about the contextualizations of their conceptualizations derived from particular spatial multiplicities. Doing so corresponds to advocating in favor of the development of theories as an "inquirybased practice."

Another practice took place under my supervision outside of the higher education classroom ${ }^{17}$, with the aim of stimulating under-graduate students to seek to promote small ruptures in terms of: a) the production of a textual/discursive genre, b) the use of spaces other than the classroom, c) the reconfiguration of an assemblage of human-nonhumans and natural, linguistic and technological resources, and d) the potential to re-signify (critically, creatively and ethically) a particular theme or event that was meaningful to them. ${ }^{18}$

One group of students, from my class, problematized the truck drivers' strike in Brazil, in 2018, taking into consideration the role of the materiality they transported, and the service delivery at all levels in the social order of that particular moment. They were supposed to rethink how their posthuman subjectivities and agencies could be reconstructed in creative and ethical performativities. The choice of this theme (truck drivers' strike), in principle, was of utmost importance for all the Brazilians. People had hardly thought of how life would be impossible without

17. This preliminary practice was promoted in the English language discipline of a language course at a public university. It was part of a broader research project, Novos letramentos e multiletramentos no ensino de línguas em letras: ressignificando em tempos globais, coordinated by the author of this article whose aim was to investigate undergraduate students' meaning making. Students had been exposed to conceptions related to critical linguistic education and they were offered the option to also experiment within materiality as another form of evaluation for this discipline, as negotiated in the beginning of that term. The students' teacher, author of this article used to make experiments with posthumanist conceptions of language/literacy and the practice discussed here was extracted from such a work.

18. This was the criterion for the activity and the planning did not follow the traditional a-z trajectory. Students were instructed to rely on contingencies following Braidotti's orientations according to the citation on page 8 in this article. 
the truck drivers' work, the everyday means of transportation (cars planes, buses, trucks, motorbikes, trucks, vans etc.) to carry workers, patients, students, citizens, animals, medications, oxygen, goods, food/feed, fuel, water, documents and now they hoped that the government would have capacity to negotiate with the strikers immediately and satisfactorily, and to compensate for the natural societal losses.

These students created a parody ${ }^{19}$ for the most popular evening TV news show in Brazil through digital resources. While one of the students reports the news, we can observe strategic uses of sound track and images of the cited program are showed in the beginning of their parody, which are then followed by scenes of the drivers' attempt to block the roads with burning materials. Police cars, an overview of the city, highways, tire barriers to impede the other drivers from proceeding and the traffic jam after the end of the strike follow. The owner of a kiosk and a professor are interviewed in locus, that is, in the university campus. In humorous ways, a driver's wife and her husband's performance provide the viewers not only with their critical positions in relation to the situation, but also with creative and multimodal meaning-making strategies. The tears in the driver's eyes, the feeling that he wanted to smile, his tone of voice, his gestures and his stealing the reporter's microphone to speak for himself are evidence of how bodies matter. Deliberately, the reporter stands strategically in the middle of a street on campus to attract other people's attention. One student (playing the role of extra) takes advantage of the situation and runs behind the reporter shouting: "Fora Temer ${ }^{20 "}$. The focus is, then, changed and the military intervention decreed by the federal government is emphasized as a true reporter from a conservative radio news show is brought to the scene to reverberates how the international press was covering both the truckers' strike and the Petrobras corruption scandal in Brazil. The news ends with the student's arguing for a non-generalizable view of the drivers, accentuating the hypothesis that the military intervention might be a means to force the government to fall.

A practice like this would not have been as meaningful and rich had it been carried out inside the classroom. One may say a more detailed exploration of the nonhuman agency could have been provided. Maybe they were not yet prepared, as they were expected to exert their agencies as an embodies and distributed process going on in different times and spaces explicitly. Nevertheless, recognizing the students' agency is crucial: "agency is a matter of intra-acting; it is an enactment.

19. https://www.youtube.com/watch?v $=\mathrm{NbO} 7 \mathrm{MuVdNoU} \&$ feature $=$ youtu.be

20. Temer was the President of Brazil at that time and "Fora, Temer!", meanin "Temer, get out!", a popular anti-government motto. 
Not something that someone or something has. Agency is doing/being in its intra-activity" (BARAD, 2007, p. 235). These students' project was a complex entanglement that emerged from: a) their objectives, strategies and semiotic resources; b) their own rematerialization of the relations of production with a specific audience ${ }_{i}$ ) their agential possibilities and responsibilities for reconfiguring of the power exerted by technology, the environment, and the agency of things; $d$ ) their perception of how the voices and actions of a less prestigious social class (truckers) might have been colonized by more powerful groups (MIGNOLO, 2000, 2010; SANTOS, 2018) and e) their process of understanding of natural, political and cultural elements and of identity formation, all shifting from separable relations to intra-activity as complex/hybrid and competing forces to be recognized. Here, nonhuman elements count as part of peoples' bodies: memories, narratives, hyperintertextuality, desires, demands and actions that contribute to the relocation of pedagogical and translingual practices (CANAGARAJAH, 1013). Proposals like this one allow students to develop their potential to undo and redo interrelationships in different and innovative scales, moving towards human-nonhuman practice.

Gearing seeing, hearing and moving towards a more integrationist approach, including multimodal and multisensory meaning-making (KRESS, 2003) also comes into play. Multisensory modes are an interconnected generator of meanings in the assemblage (CANAGARAJAH, 2013) or "vibrant matter" along with humannonhuman "conflicting degrees of power and effectivity" (BENNET, 2010, p. 3337 ) and these modes are placed at the forefront to understand what distributed agency among such elements means (PENNYCOOK, 2018, p. 16). Also, "vitality in difficulty to deal with the exuberant logics [...] rather than crisis and mutual respect among diversity" is recommended by Braidotti (2018, p 157), who feels the need for more dialogues across the limits and possibilities of a range of perspectives.

The entanglement of less frequent materiality (the microphone and camera, instead of the board, chalk and classroom space) at least in language classes, with the choice of a less prestigious social class (truck drivers), the use of the campus the way it is/was and the unexpected interaction with the owner of the kiosk, the climate conditions and the students' symbolic capital (BOUDIEU, 1991), and histories, as they are entangled in this example, all attest that bringing nonhuman and non-human agencies to the same plane tends to broaden the Bakhtinian concept of language and allow for a conciliation of studies in applied linguistics, literacies' research and posthumanism in education.

An initiative like this might enhance possibilities of new points of interlinked spirals of becoming expanding the flows of contingencies and transgressions to 
reconstitute identities, intersubjectivities and distributed agencies in "intra-acting human and posthuman energies" (BENNET, 2010, p. 130), discourses and materiality. Central to posthumanist literacies is the recognition that the contemporary self/ other, or we/they already live in posthuman conditions. Such conditions are heterogeneous and require a recasting of what counts as relevant thinking and doing with and against mainstream and worn out dichotomies such as human/nonhuman, classroom/society, culture/nature. The fact that the undergraduate students in the above example denounced the drivers' negative situation indirectly means that fuel and services were, for the students, immaterial things - in the sense that they didn't matter to them - that finally really "mattered" to them, as their material agencies acquired a political dimension in such a context. While the drivers had their motives to go on strick, they were not outside the neoliberal assemblage and, in this sense, posthuman applied linguistics operates within the minorities but from inside hegemonic structures.

Intra-actions in the urban space were investigated by another student ${ }^{21}$ taking English language VII, of the forth term of a four-year language course at a public university. The aforementioned student used the circulation and the movements (far from being politically neutral) of the people in his town, including the streets sings, cars, bikes, motorbikes, shops and the mobile phones some of these people carried while walking along the streets as material markers of the structural, social, cultural, economic dimensions of relations of power. He assumed "new possibilities open up as others that might have been possible are now excluded", as Barad puts it $(2007$, p. 234).

For two weeks, he set out to investigate how people behaved while reading the signs on the streets (or not) while at the same time checking their mobile phones. The notion of agency adopted was an ongoing one, that is, a vibrant reconfiguring of human-cellphone becoming, as the continuous dynamism of the enfolding of mattering. Sometimes the scenes were filmed by himself using his mobile phone as he stood on a corner. On other occasions, he walked along or crossed the streets to follow the people who might be texting on or talking to other people on their cell phones. Two situations captured were remarkable. In the first one, a famous journalist was caught crossing a street talking on her cell phone. On interviewing

21. This preliminary activity was promoted within the project "Novos Letramentos e Multiletramentos no Ensino de Línguas em Letras: ressignificando em tempos globais", coordinated by me, of which the aim was to investigate undergraduate students' meaning making practices. Students had been exposed to conceptions related to critical linguistic education and they were offered the option to also experiment within materiality as another form of evaluation for this discipline, as negotiated in the beginning of that term. 
her, the student was told this was a common practice among cellphone users in public spaces and the streets were one of them, implying that nothing surprising should be seen in the fact, mainly as regards busy professionals like her having to meet their boss's demands. This example, the student concluded, troubled the common notion that her cell phone, the pedestrian crossing, the traffic lights, the vehicles, the motorbikes, and the bikes, the other bypassers' agencies were isolated from the journalist. They were all actants. He proceeded to explain that a 'geared' assemblage could be identified in which uneven distribution of forces among the actants resulted in enabling her to give more attention to the institutional duties (her phone conversation is evidence of this) and less to the danger of crossing the street in that moment. It was "as if she was being conducted by the machine rather than by her rational thinking based on conventional norms for pedestrians", the student declared. It is our understanding that materiality gets empowered by our exposing the non-naturalistic structure (BRAIDOTTI, 2018) of the jaywalker.

The second situation, which brought vibrant color to disrupt fixed ideas in relation to social agency, brought challenges to the student. He permitted himself to be exposed to a new situation: to follow and film a colleague who was cycling and heading for the university campus with a cell phone on his right hand. Without being noticed by this colleague on the bicycle, the student decided to secretly shoot the scene by following the biker's trajectory while hiding behind trees, cars, shops and people on the streets. This practice revealed a moment in which the cyclist almost fell down, as he did not resist checking something on his cell phone.

The cell phone itself was more than a transgressor with the ability to influence and cause a change in the biker's behavior. It took on a certain position and function in space not to be taken for granted. Far from being inert and innocent, the cell phone was already part of the whole phenomenon in motion, blurring the physical boundaries between the horizon (the paving stone, the bike, its handlebar, the street signs, the tress, the daylight, other people and vehicles) and the digital screen in which the cyclist's eyes, hands and body were enmeshed. The need for placing restrictions to cycling, carrying and accessing a mobile phone while in motion means that places and events are made through one another, each one responding to what will happen and what will be possible (or not), so that neither the place nor the event is an "immediate givenness", as Barad says (2007, p. 244). For the student, to holding the theories studied in the classroom in her hand is very different from doing research echoing the appreciation of humannonhuman embodied experience. Prefabricated notions of object and subject were problematized by the cited student who expressed the need to pursue intelligibility 
by asking herself "if the cell phone could speak". Barad (2007, p. 335) argues that "to assume meaning is a property of individual words or groups of words is to stay within a linguistic framing of meaning making." The proposition suggests that "intelligibility is not an inherent characteristic of humans but a feature of the world in its differential becoming" (BARAD, 2007, p. 335) in ways that "the world articulates itself differently" (2007, p. 335), a position which is similar to what Braidotti (2018, p. 104) defends if "planetary subject formations" are desirable. In this ethical posthuman perspective, the student had the opportunity to revitalize and expand conceptions of actants, agency in a townscape mobilizing questionings and reflections beyond the stigmatized centrality of the humans.

Acknowledging that machinic assemblages are nonhuman agencies functioning through material capacities ${ }^{22}$ leads to the promotion of a radical break among "regimes of signs and their objects" assert Deleuze and Guattari (2005, p. 28). Such a proposition indicates agency circulates in multiple and dynamic ways rather than being attributed to only humans (BARAD, 2017; BENNET, 2010, PENNYCOOK, 2018; TAYLOR; HUGHES, 2016).

Hence, this activity signals to preliminary insights for the reworking of other ontologies, epistemologies and ethics in language and planet studies to become possible. The notion of agency put forward by Barad is instrumental:

Agency is a matter of intra-acting; it is an enactment, not something that someone or something has. Agency cannot be designated as an attribute of "subjects" or "objects" (as they do not preexist as such). Agency is not an attribute whatsoever-it is "doing"/"being" in its intra-activity. Agency is the enactment of iterative changes to particular practices through the dynamics of intra-activity (BARAD, 2017, p. 26-27, quotation marks in the original).

In the two scenes described above, the student's agency is, therefore, closely related to the expansion of a situated performativity that demonstrates "the locus of agency is always a human-nonhuman working group" (BENNET, 2010, p. xvii) offering possibilities of becoming each time human-nonhuman bodies act/enact/ intra-act. These becomings are something language per se may not cater for, in spite of its excessive historically granted power.

From an international context, another illustrative research can be about learning from and with indigenous ontologies, such as those from the Maoris, studied by Jones and Hoskins (2016). These studies show that it might be wise to engage with nonhumans in interminable tension, which is both positive and necessary. This endeavor does not mean there is a winner and a loser. The idea is to

22. See, for example, Roberts (2012). 
accentuate what has not yet become known. As Maori scholars, Jones and Hoskins (2016) illuminate this notion by discussing how the facial tattooing of a Maori leader, Hongi Hika, requires a "radical collapse of the subject-object dualism" (JONES; HOSKINS, 2016, p. 77) to "meet the drawing in organic fashion, that is, placing the Maori leader as a 'speaking subject' instead of a mere object of study". Abounding genealogical traces and narratives are part of the active engagement with Hongi Hika and the viewers who are also participant in this encounter. Cultivating posthuman interpretivist procedures presupposes understanding that

indigenous peoples .... engaged with an environment that was always already formed by powerful and weak forces and objects, where human beings bad to negotiate with a capricious natural world on a daily basis. Developing outside Europe, Indigenous ontologies never had a nature-culture dualism, never truly differentiated 'culture' and 'nature' (JONES, HOSKINS, 2016, p. 79, italic emphases and quotation marks in the original).

As suggested in this quotation, if humans had to negotiate with nature, then rivers, mountains etc. would be animated beings in their own right, with potentiality to tell people something or to instruct them. "In this sense, the object acts. The object speaks, it makes demands and it draws forth from us a response", argue Jones and Hoskins (2016, p. 80, italic emphasis in the original). A social practice that was part of this research among the Maori consisted of interacting with nonhuman forces called "karakia" to "enable the research to proceed well", Jones and Hoskins (2016, p. 80) add. It involved conjuring the vitality of elements, such as earth, sky, spaces, multiple bodies and people's ancestors. It is clear that there is more than mere language here, that is, something that goes beyond and exceeds the humanonly we/they Freirean relation, as already mentioned.

A challenge remains for the cited Maori scholars: to move away from human oriented methodology or to persevere and revise it resulting in more evanescent but prosperous field of perceptions and intra-actions. Bennet's (2010) orientations to work on the politics between Western tradition (use of paper, ink and language that Europeans understand as in the case of the drawing) and Maori traditions (what is to be experienced in incommensurable meaning systems, but cannot be expressed in the same way) might open up paths for the scholars to embark on new projects.

Research and cases like the ones showcased in this paper may only scratch the surface of posthumanist applied linguistics. However, they favor the recognition of important directions for unknown future entanglements of nature-science paradigm. Dislocating traditional views of mankind and communication centered on spoken and written languages, including human-nonhuman ontologies and other than human ways of being in this universe entails a joint effort of applied linguistics and other language and literacy researchers to make explicit the different intra-active engagements enacting differential becoming. This means engaging with questions 
and projects based on the assumption of that human we-they and nonhuman wethey relationships can be interweaved in ways that expand the ethics of natureculture, nonhuman ontologies and planet studies always already in present times.

Food for thought would be to fall back on Barad's (2007) reclaims towards granting status to (non)human concepts, practices and knowledge at the foundation of theories, as illustrated by the examples above taken from my practice at the university and by Jones and Hoskins' (2006) reminders of the indigenous' ontological entanglements. These examples of meaning making appear to travel across differences in which the process of becoming in central in posthuman entanglements.

\section{BECOMING...}

This work has mapped some of the emerging trends in posthumanism signaling ontological, epistemological and methodological changes in research in applied linguistics and literacy studies more compatible with our current condition. Towards this goal, a key lesson from critical posthumanism might be to engage with planetary ways (BRAIDOTTI, 2018) of living, teaching and researching while assuming the recognition that neoliberal matrixes of power in the name of capitalism and modernity have to be resisted and transformed.

Choosing to proceed in entangled ways (BARAD, 2003), that is, to construct knowledge and develop 'human-nonhumakind' with strategies and criteria, rethinking how grass-rooted participation of the other-material things makes sense of life can contribute to the emergence of fluid assembles of meanings, not-yet-named materials and insights for queering received meanings of language, discourse, agency and ecology.

Given that the frequent technology mediated forms of knowledge and meaning-making, the constant fluxes of migrants and capitals in globalization, and the natural disasters modifying the health of the planet (such as tsunamis, earthquakes, volcanos, garbage disposal, animal extinction) are as creative, active and mutable as complex ontological forces, they also constitute humans, which renders the separation between culture and nature nonsensical.

The conclusion of this theoretical provocation of thoughts indicates that human-nonhuman research calls for applied linguistics and literacy studies willing to recognize that they themselves are products of human-nonhuman entanglements.

In this direction, the oppressed, the emancipated, and the tolerable in conventional pedagogies might not be only in the realm of the humans, but rather in 
open processes of intersubjectivities, identities and narratives for becoming other(s) as already delineated here. In this way, reengaging politically with reformulated conceptions of language, knowledge and agency, within a wider range of semiotic, spatial and ethical complexities, in the emergence of posthuman humanism, as Braidotti (2018) postulates it, appears to inform and engender responses in our ubiquitous everyday coexisting practices.

\section{REFERENCES}

BARAD, K. (2007). Meeting the universe balfway: quantum physics and the entanglement of mater and meaning. Durham, N.C.: Duke University Press.

BARAD, K. (2012). "Intra-actions" (interview of Karen Barad by Adam Kleinmann). Available at: < https://www.academia.edu/1857617/_Intra-actions_Interview_of_Karen_Barad by_Adam_Kleinmann.> Access on: December 102018.

BARAD, K. (2003). Posthumanist Performativity: Toward an Understanding of How Matter Comes to Matter. Available at: <https://www.uio.no/studier/emner/sv/sai/SOSANT4400/ v14/pensumliste/barad_posthumanist-performativity.pdf $>$. Access on: January 15, 2019.

BOURDIEU, P. (1991). Language and symbolic capital. Cambridge: Polity Press.

BRAIDOTTI, R. The posthuman. (2018). Cambridge: Polity Press, 2018.

BENNET, J. Vibrant matter. A political ecology of things. (2010). Durham, NC: Duke University Press.

CANAGARAJAH, S. Translingual practice: global Englishes and cosmopolitan relations. (2013). New York, London, Routledge.

DELEUZE, G.; GUATTARI, F. (2005). A thousand plateaus: capitalism and schizophrenia/ Gilles Deleuze, Felix Guattari; translation and foreword by Brian Massumi. Minneapolis: Published by the University of Minnesota Press, 2005.

FRANKLIN, S.; LURY, C.; STACEY, J. (2000). Global nature, Global culture. London Sage.

FREIRE, P. (2011). Pedagogia do oprimido. 50a . ed. Rio de Janeiro: Paz e Terra.

FREIRE, P. Pedagogy of the oppressed. (2017). 50 th anniversary edition. Translated by Myra Bergman Ramos. With an introduction by Donaldo Macedo and an afterword by Ira Shor. New York: Bloomsbury Publishing Inc. 
GUATARRI, F. (1995). Chaosmosis. An ethico-aesthetic paradigm. Sidney: Power Publications.

HACKETT, A.; SOMERVILLE, M. (2017). Posthuman literacies: young children moving in time, place and more-than-human worlds. Available at: https://e-space.mmu. ac.uk/618199/3/Moving\%20in\%20time\%20and\%20place\%20FINAL\%20\%20 March\%202017\%20(4).pdf. Access on: January 15, 2019.

JONES, A.; HOSKINS, T. K. (2016). A mark on paper: the matter of indigenous-settler history. In: TAYLOR, C.; HUGHES, C. (Eds.) Postbuman research practices in Education. New York: Palgrave Macmillan, p. 75-92.

KRESS, G. (2003). Literacy in the New Media Age. New York, London: Routledge.

LATOUR, B. (2005). Reassembling the social: an introduction to actor-network theory. Oxford: Oxford University Press.

LIVESEY, G. (2010). Assemblage. In: PARR, A. (Ed.) Deleuze dictionary. Revised edition. Edinburg: Edinburg University Press, p. 18-19.

MIGNOLO, W. (2000). Local bistories/global designs. Coloniality, subaltern knowledges, and border thinking. Princetown: Princetown University Press.

MIGNOLO, W. (2010). The geopolitics of knowledge and the colonial difference. Disponível em: $<$ http:// waltermignolo.com/the-geopolitics-of-knowledge-and-the-colonialdifference/ $>$. Access on January 17, 2019.

MITHCELL, D. T.; SNYDER, S. L. (2015). The Biopolitics of Disability: Neoliberalism, Ablenationalism, and Peripheral Embodiment. Ann Arbor: University of Michigan Press.

PENNYCOOK, A. (2018). Posthumanist applied linguistics. New York: Routledge.

PENNYCOOK, A. A linguística aplicada dos anos 90: em defesa de uma abordagem crítica. In: SIGNORINI, I.; CAVALCANTI, M. (Orgs.) (2007). Linguística aplicada e transdisciplinaridade. Campinas: Mercado de Letras.

PENNYCOOK, A.; OTSUJI. E. (2015). Metrolingualism. Language in the city. London, New York: Routledge.

PHILIPS, J. (2006). Agencement/Assemblage. Available at: < http://www.urbanlab.org/articles/ Philips\%20asse,blages.pdf $>$. Access on: December 20, 2018.

QUIJANO, A. Coloniality and modernity/rationality. In: MIGNOLO, W.; ESCOBAR, A. (Eds.) Globalization and the decolonial option. London, New York: Routledge, 2013, p. 22-32. 
ROBERTS, T. (2012). From 'new materialism' to 'machinic assemblage': agency and affect in IKEA. Available at: < https://journals.sagepub.com/doi/10.1068/a44692>. Access on: January 31, 2018, from.

SAID, E. (2004). Humanism and democratic criticism. New York: Columbia University Press.

SANTOS, B. de SOUSA. (2018). Para uma nova visão da Europa aprender como sul. In: SANTOS, B. de SOUSA; MENDES, J. M. (Orgs.) Demodiversidade. Imaginar novas possibilidades democráticas. Belo Horizonte: autêntica, 2018, p. 51-72.

SHIVA, V. (1997). Biopiracy. The plunder of nature and knowledge. Boston, MA: South End Press.

SOUZA, L. M. T. (2011). Para uma redefinição de letramento crítico: conflito e produção de significação. Available at: < https://www.researchgate.net/publication/236003625 Para_uma_redefinicao_de_letramento_critico_conflito_e_producao_de significacao. $>$ Access on: January 19, 2019.

TAKAKI, N. H. (2019). É o que somos, sendo: o papel da autocrítica nos letramentos. In: FERRAZ, D. M.; KAWACHI-FURLAN, C. J. (Orgs.) Bate-papo com educadores linguísticos: letramentos, formação docente e criticidade. Campinas: Pontes Editores, p. 197-216.

TAKAKI, N. H. (2016). Epistemologia-ontologia-metodologia pela diferença: locus transfronteira em ironia multimodal. Trabalhos em Linguística Aplicada, v. 55, p. 1-26.

TAYLOR, C.; HUGHES, C. (Eds.) (2016). Posthuman research practices in Education. New York: Palgrave Macmillan.

TAYLOR, C. Edu-crafting a cacophonous ecology: posthumanist research practices for education. In: TAYLOR, C.; HUGHES, C. (Eds.) (2016). Posthuman research practices in Education. New York: Palgrave Macmillan, p. 5-24.

THORBURN, E. D. (2015). Human-Machinic Assemblages: Technologies, Bodies, and the Recuperation of Social Reproduction in the Crisis Era. Available at: < https://ir.lib. uwo.ca/cgi/viewcontent.cgi? article $=4331 \&$ context $=$ etd $>$. Access on: January 13, 2018.

WERNICK, A. (2006). University. Theory, cultures, society, v. 23 (2-3), p. 557 - 579.

Recebido: 1/06/2019

Aceito: 6/07/2019

Publicado: 12/07/2019 